TEME, г. XLIII, бр. 4, октобар - децембар 2019, стр. 997-1011

Прегледни рад

Примљено: 14. 10. 2019.

https://doi.org/10.22190/TEME191014059K

Ревидирана верзија: 15. 10. 2019.

UDK 343.13:343.982

Одобрено за штампу: 1. 12. 2019.

$342.7: 343.45$

\title{
APPLICATION OF THERMAL IMAGING CAMERAS IN CRIME DETECTION ${ }^{a}$
}

\author{
Tanja Kesić*, Ivana Bjelovuk
}

University of Criminal Investigation and Police Studies, Belgrade, Serbia

*tkesic8@gmail.com

\begin{abstract}
The application of thermal imaging cameras in crime detection has raised the question of the legality of their use, as well as the procedural value of thus obtained information. With regard to these questions, the standpoint of the U.S. court practice has shown diametrically opposite views. The earliar U.S. courts rulings took the position that the application of thermal imaging cameras was not subject to the fulfillment of any particular conditions and that it was encompassed by police discretionary decisions. The position of later rulings was that the application of new technologies, including thermal imaging cameras, was subject to basic conditions required for searching, i.e. mandatory obtaining of the court order with the purpose of protecting the right to privacy. As the application of thermal imaging cameras in the Republic of Serbia is prescribed neither by laws nor by by-laws, it could be governed by general regulations on the use of technical means in implementing operational tactical measures and actions, as well as gathering of evidence. Therefore, thermal imaging cameras might be used in police actions, such as police observation, covert surveillance and recording. In the course of covert surveillance and recording, as part of theevidence gathering process, the use of thermal imaging cameras would be regulated by the same conditions by which the undertaken actions are regulated. Since the possibility of the application of thermal imaging cameras while performing police observation is not explicitly provided for, dilemmas with regard to their use still remain, as well as the issues concerning their procedural value.
\end{abstract}

Key words: thermal imaging cameras, crime detection, privacy.

\footnotetext{
${ }^{a}$ This paper is the result of the realisation of the Scientific Research Project entitled "Development of Institutional Capacities, Standards and Procedures for Fighting Organized Crime and Terrorism in Climate of International Integrations". The project is financed by the Ministry of Education, Science and Technological Development of the Republic of Serbia (No 179045) and carried out by the University of Criminal Investigation and Police Studie (2011-2019).
} 


\title{
ПРИМЕНА ТЕРМОВИЗИЈСКИХ КАМЕРА У ДЕТЕКЦИЈИ КРИМИНАЛА
}

\begin{abstract}
Апстракт
Примена термовизијских камера у детекцији криминала отворила је питање законитости њихове употребе и процесног значаја тако добијених информација. У одговору на ова питања пракса америчких судова заузимала је дијаметрално супротстављена гледишта. Старије пресуде америчких судова су полазиле од схватања да примена термовизијских камера не подлеже испуњавању никаквих посебних услова и да потпада под полицијско дискреционо одлучивање. Касније пресуде заузимају став да примена нових технологија, па и термовизијских камера, подлеже основним условима који се траже за претресање, односно обавезном прибављању судске наредбе, а све у циљу заштите права на приватност. Примена термовизијских камера у Републици Србији није прописана ниједним законом или подзаконским актом, већ би се могла подвести под опште одредбе о употреби техничких средстава при спровођењу оперативно-тактичких мера и радњи и доказних радњи. Као радње при чијем спровођењу би могло доћи до употребе термовизијских камера издвајају се полицијско опажање и тајно праћење и снимање. Приликом примене тајног праћења и снимања, као посебне доказне радње, примена термовизијских камера била би уређена под истим условима под којима се и сама радња предузима. Дилеме постоје код примене термовизијских камера при спровођењу полицијског опажања, будући да та могућност није експлицитно предвиђена, а тиме је остало без одговора и питање њиховог процесног значаја.
\end{abstract}

Кључне речи: термовизијске камере, детекција криминала, приватност.

\section{INTRODUCTION}

Modern society is characterized by numerous challenges, among which those regarding safety may be singled out as the most important. Safety issues presents a fundamental and primary concern since both society and its members may fully develop only in a safe environment. The safety of an individual and the community is not an isolated issue with which a state, region or an organization have to deal with, but a universal problem asking for multiagency approach, internal and international normative and operational response (Nikač, Radovanović, Zorić, 2018, p. 204). One of the biggest safety threats arises from the perpetration of various criminal acts. Dealing with safety protection, i.e. prevention, detection and the proving of criminal acts, modern societies use advanced technologies to a great extent. One of these technologies applied in crime detection is the utilization of thermal imaging cameras.

Thermal imaging cameras record heat emission, converting infrared radiation into radiation visible to the human eye. Infrared light is used for identifying the presence of bloodstains, the detection of writing ink, the examination of burned documents, the detection of gunshot residue (GSR), trace impression evidence, etc. Law enforcement officers use thermal imaging cameras mostly for the detection of illegal marijuana 
growing, human trafficking and state border surveillance. The U.S. applies this technique as the basis for obtaining a search warrant if there is probable cause that a person is cultivating cannabis illegally.

The utilization of thermal imaging cameras in crime detection has raised two questions. The first question refers to the lawful use of thermal imaging cameras with regard to the protection of the right to privacy, while the second one deals with the issue of the procedural value of the information obtained by means of thermal imaging cameras. With the aim of answering these questions, the first part of the paper presents the basic features of infrared thermal imaging technology and its potential areas of application. The second part of the paper analyzes some of the most significant rulings of the U.S. courts pertaining to the use of thermal imaging cameras in crime detection and protection of the right to privacy. The third part of the paper deals with the positive legal solutions in the Republic of Serbia with reference to the application of thermal imaging cameras.

\section{INFRARED THERMAL IMAGING TECHNOLOGY}

Infrared radiation is the range of electromagnetic specter of radiation that arises from the thermal radiation with longer wavelengths than visible light and shorter wavelengths than microwave radiation. (Asirdizer, et.al., 2016, p. 98). It is in range from 700 $\mathrm{nm}$ to $30 \mu \mathrm{m}$ and it is used for the detection of emitted heat. Each object in nature that has a temperature above the absolute zero $\left(0 \mathrm{~K}=-273^{\circ} \mathrm{C}\right)$ emits radiation in the infrared range of electromagnetic spectra because it is hotter than its surroundings and cools down by transferring energy through convection, conduction and radiation. There are three types of infrared radiation: near, mid and thermal infrared radiation (Battalwar, et.al., 2015, p. 11; Chua, et.al., 2018, p. 1). The relation between the amount of emitted energy by the object and the temperature is given as Stefan-Boltzman law (Equation 1) (Edelman, et.al., 2013, p.1157).

$$
W=\sigma \varepsilon T^{4}
$$

$W$ stands for the total amount of energy per square meter $\left(W / \mathrm{m}^{2}\right), \sigma$ $=5.67 \times 10^{-8} \mathrm{Wm}^{2} / \mathrm{K}^{4}$ is Stefan-Boltzman Constant, $\varepsilon$ is emissivity, and $T$ is absolute temperature $(K)$.

Infrared thermal imaging is a contactless and nondestructive technique which detects temperature changes of a recorded object. Initially, infrared technology was developed for military purposes. This technology can be applied to any situation where thermal profile and temperature will provide information about an object (Battalwar, et.al., 2015 , p.10). The equipment needed for thermal imaging involves a camera and computer with the appropriate software for saving and 
subsequent image processing. An infrared camera converts invisible light into visible images, similar to a common camera which uses visible light.

The working principle of a thermal imaging camera is based on the passing of infrared rays through a specific lens, which subsequently focus passing through a sensor. In order to avoid reflection, this lens is not made of ordinary glass, but of $\mathrm{Ge}, \mathrm{SiO}_{2}, \mathrm{ZnSe}, \mathrm{ZnS}$ (Edelman, et.al., 2013, p. 1160). The obtained information visible as numerous dots of a recorded object is processed and displayed in the form of a thermal image by the sensor in a very short time. Digital sensors are made to be sensitive to wavelengths of infrared rays. Digital technology converts a thermal image into electrical impulses directed toward the unit for signal processing and the system for image acquisition. A thermal image is dyed in various colors depending on the emitted energy of the recorded object.

Regarding the fact that the temperature measuring of the recorded object is a non-contact method, a number of factors, such as the quality of the recorded object surface, i.e. its emissivity, reflectivity, distance between the device and the recorded object, environment temperature, etc. act on the recorded temperature values. A lot of research has been done all over the world in order to improve the accuracy of temperature measurement with the use of infrared thermal imager (Zhang, et.al., 2019, p. 1).

Nowadays, advances in technology have made infrared digital imaging available to forensic photographers. Infrared light has wide application in forensic science in developed countries. It can be used both at the crime scene and in the laboratory. Thus, infrared light is used for identifying the presence of bloodstains, detection of writing ink, examination of burned documents, detection of gunshot residue (GSR), trace impression evidence, such as tire prints on dark clothes, biomedical photography, surveillance photography, etc. (Lyn, et.al., 2007, p. 1148; De Broux, et.al., 2007, p. 1).

Thermal traces found at the crime scene may lead to information when a certain object was used, i.e. when it was in contact with a warm object, e.g. if there was any electrical devices, cups or any other containers with lukewarm liquid (Edelman, et.al., 2013, p. 1161). Furthermore, thermal imaging can be used for the estimation of cooling time from pixel intensity values within a time interval of 3 to 25 minutes after shoes have been removed from the crime scene, which means that it would be possible to assess the amount of time since a suspect has left the crime scene (Chua, et.al., 2018, p. 1). With the use of thermal infrared camera technology, it is possible to identify the source of the failure and track its path. Moreover, it can be used for looking through the smoke.

Thermal imaging of a person's face is used in order to estimate their current functional and psycho-emotional state based on the analysis of parameters which characterize the work of the respiratory and the cardiovascular system. The change of temperature of the facial areas near 
the bridge of the nose is in direct relation to the parameters of the cardiovascular system (Alyushin \& Kolobashkina, 2018, p. 44). Thermal imaging is also applied in firefighting operations, military, law enforcement and anti-terrorism, automotive applications, roof inspection, medical imaging, night vision, medical field, police target detection and acquisition (Battalwar, et.al., 2015, p. 13). Infrared thermal imaging technology is a new technology which is applied in police practice in the Republic of Serbia.

\section{THE APPLICATION OF THERMAL IMAGING CAMERAS IN CRIME DETECTION IN THE USA}

The U.S. police agencies started using thermal imaging cameras in the early 90 s of the $20^{\text {th }}$ century. Therefore, courts had to decide if the use of thermal imaging constituted search under the Fourth Amendment (Dashiell, 2003, p. 360). In the USA, thermal imaging is dominantly used for the detection of illegal laboratories for the cultivation of cannabis as proof for reinforcing the request for the search of specified premises. Therefore, in the practice of the U.S. courts, the question arises as to whether this evidence should be seen through the prism of the protection of the right to privacy, i.e. the Fourth Amendment to the Constitution of the U.S. According to this Amendment, "the people have a right to be secure in their persons, houses, papers, and effects, against unreasonable searches and seizures, shall not be violated, and no warrants shall issue, but upon probable cause, supported by oath or affirmation, and particularly describing the place to be searched, and the persons or things to be seized". The Fourth Amendment issue raised by thermal imaging technology is whether the use of the device by the law enforcement constitutes a search within the meaning of the Fourth Amendment.

In the beginning, the majority of the U.S. courts held that thermal imaging was not a search and accepted thermal image as evidence although the warrant for a search was not obtained. The majority of views of the courts mentioned relies on several different rationales. One rationale posits that thermal imaging is non-intrusive and, therefore, not a search, comparing it to the search of the garbage disposed of by the suspect. In California v. Greenwood (486 U.S. 35, 40,1988), the Court held that it was not a Fourth Amendment violation to search a person's garbage without a warrant. The Court reasoned that one had no subjective expectation of privacy in that which he knowingly exposed to the public "the garbage could be inspected by anyone". Nor does one have a privacy interest in that which is knowingly transferred to a third party, the garbage collectors. The District Court of Hawaii in United States v. PennyFeeney concluded that the disposal of waste matter was exposed to the public and, therefore, the defendant had no subjective expectation of 
privacy. Even if he did, the court said, the defendant's expectation would be unreasonable, because "no intimate details connected with the use of the home or curtilage were observed". Furthermore, the court wrote, the Fourth Amendment was not violated because the thermal imager was passive, "there was no undue noise, no wind, dust, or threat of injury" (Dashiell, 2003, pp. 360-361).

Another rationale analogizes thermal imaging to canine sniffs. The Eighth Circuit in United States v. Pinson reasoned that thermal imaging was "analogous to the constitutional and warrantless use of police dogs trained to sniff and identify the presence of drugs." The Pinson court stated: "Just as odor escapes a compartment or building and is detected by the sense-enhancing instrument of a canine sniff, so also does heat escape a home and is detected by the sense-enhancing infrared camera." The court also discussed the fact that no intimate details of the home were observed by the thermal imaging.

Finally, some courts justified the use of thermal imaging on the plain view doctrine for a search (Campisi, 2001, pp. 257-258). In United States v. Ishmael, the Fifth Circuit found that the defendant did have a subjective expectation of privacy, but held that the expectation was unreasonable. In this case the court compared the use of the thermal imaging device to law enforcement officers peering into a barn located in an open field. Thus, the defendants had no reasonable expectation of privacy because their secret marijuana crop was inside a building in an open field, and no search occurred because the building was never physically invaded (Dashiell, 2003, p. 362).

Only a minority of the U.S. courts considered that law enforcement officers must obtain a court warrant for this type of evidence because it would otherwise constitute a search under the Fourth Amendment. These courts focused on the intrusive nature of this technology. The view of these courts also focused on the individual's expectation of privacy in the activities conducted within the home, rather than on the expectation of privacy in the heat emitted from the residence. The turning point in the court practice concerning the use of technology in the protection of the right to privacy was the ruling in the Katz $v$. United States case because it took the view that the Fourth Amendment protects people, not places. In support of this view, it should be emphasized that the evidential value of the information obtained by communication surveillance without physical intrusion into a particular place has to be judged by the standard of the fulfillment of the search warrant requirement. Justice Harlan suggested a two-part test for assessing the violation of the right to privacy in this case. The first test referred to the assessment of the subjective expectation of the person whose premises had been searched. The second test was to assess whether that subjective expectation regarding privacy was recognized as reasonable by society (McKenzie, 2002, p. 158). 
Subsequent to this ruling, in the State v. Siegel case, the Montana Supreme Court held that the use of thermal imagers in criminal investigations constituted a search under the Montana Constitution, thereby requiring a search warrant supported by probable cause. The court in the State v. Siegel case noted that thermal imaging provided information regarding heat emissions of both illegal and legal nature, finding that a thermal imager could not limit its detection solely to information regarding illegal activities and that was why a thermal imager was indiscriminate (Larks-Stanford, 2000, p. 599).

In the California v. Ciraolo case, the police received an anonymous tip that the suspect was cultivating marijuana in his backyard, the police surveilled the area from a plane in order to make sure whether marijuana was actually grown there. The police were forced to fly over the yard because the defendant had erected a six-foot outer fence and a ten-foot inner fence around it, preventing people from viewing the yard at ground level. The Court held that this was sufficient manifestation of an expectation of privacy on the defendant's part. However, the Court stated that this expectation of privacy was not one that society would find reasonable and, therefore, the defendant had failed the second prong of the Katz test. The Court reasoned that any member of the public flying over the house could have glanced down and seen what the officers had seen and concluded that the investigation did not violate the Fourth Amendment. One of the justices wrote a dissenting opinion claiming that the taken photos had revealed not only marijuana but a pool and a yard, as well. The dissenting opinion also pointed out that the technology used, specifically the airplane, allowed the police officers to conduct the investigation in a way that only would have been possible with physical invasions at the time the Fourth Amendment was adopted (McKenzie, 2002, p. 163).

Other courts stated that the use of thermal imaging devices reveal intimate details occurring within the sanctity of the home, the place deserving the utmost protection pursuant to the Fourth Amendment (LarksStanford, 2000, p. 591-593). This stance was used in the Dow Chemical Co. v. United States case, which involved fly-over and photographing by investigators, but the airplane and the camera were significantly more sophisticated than those used by the general public. The Court stated that "highly sophisticated surveillance equipment not generally available to the public, such as satellite technology, might be constitutionally proscribed absent a warrant. But the photographs here are not so revealing of intimate details as to raise constitutional concern" (McKenzie, 2002, p. 164).

The Supreme Court put an end to the mentioned discussion in the Kyllo v. United States case. In this case, the suspect's house was scanned with a thermal imaging device which revealed a huge amount of heat radiating from it. This thermal imaging scanning and the information about the electric power consumption were the basis for obtaining a search warrant. Lower courts concluded that the thermal scanner used on Kyllo's home 
measured the heat being emitted from the outside of the walls of the house. However, there appears to be little agreement on how much this tells the officers about what is going on inside the home. The court stated: "It appears that there is a variety of thermal imagers available and while some are only capable of providing crude images of where heat is coming from, others have the capability to unveil more detail." In this case, the trial court found that the thermal imager that the police used "is a non-intrusive device which emits no rays or beams and shows a crude visual image of the heat being radiated from the home outside of the house". It further found that: "The use of the thermal imaging device here was not an intrusion into Kyllo's home. No intimate details of the home were observed, and there was no intrusion upon the privacy of the individuals within the home. The device used cannot penetrate walls or windows to reveal conversations or human activities. The device recorded only the heat being emitted from the home".

In this case, the U.S. Supreme Court accepted a new test for the assessment of the application of sense-enhancing technology, thus rejecting Katz test and introduced substantial change in the Fourth Amendment law. The Court stated: "We think that obtaining by sense-enhancing technology any information regarding the interior of the home that could not otherwise have been obtained without physical intrusion into a constitutionally protected area constitutes a search - at least where (as here) the technology in question is not in general public use". The court stated: "It would be foolish to contend that the degree of privacy secured to citizens by the Fourth Amendment has been entirely unaffected by the advance of technology". Additionally, the Court noted: "Where, as here, the Government uses a device that is not in general public use, to explore details of the home that would previously have been unknowable without physical intrusion, the surveillance is a search and is presumptively unreasonable without a warrant" (Kyllo v. United States, (99-8508) 533 U.S. 27, 2001, F.3d 1041, reversed and remanded). A dissenting opinion was given by Justice Stevens. The dissent argued that there was a difference between technology that gave its user direct access to information in a private area and technology that only allowed its user to make inferences about what might be going on inside that private area. In his dissent, Justice Stevens emphasized that "what a person knowingly exposes to the public is not a subject of the Fourth Amendment protection".

Some U.S. authors point out that when using new technologies, priority should be given to obtaining a person's consent for their application. "Obtaining consent, after all, is simpler, faster, and less burdensome than applying for a warrant. As Justice Alito surmises, sometimes individuals might appreciate the opportunity to make a choice whether to consent to police intrusion into their personal and private lives or not" (Crocker, 2013, p. 736). 


\section{NORMATIVE REGULATIONS OF THE APPLICATION OF THERMAL IMAGING CAMERAS IN CRIME DETECTION IN THE REPUBLIC OF SERBIA}

Bearing in mind the importance and scope of application of thermal imaging cameras in crime detection, this part of the paper presents and analyzes the positive legal solutions pertaining to the application of thermal imaging cameras in the Republic of Serbia. Theoretically researching the subject matter of this problem, we have analyzed the most important laws and by-laws which directly regulate police powers. The basic legal act regulating the types of police duties, measures and actions undertaken by police officers is the Law on Police. However, this Law contains no regulations providing the possibility of application of thermal imaging cameras in crime detection and the state border protection. Therefore, we have analyzed the police observation or surveillance activity (Law on Police, 2016, art. 47, para. 2, item 3), since it involves the application of various advanced technology devices, including thermal imaging cameras.

Police observation is undertaken with the aim of investigating the obtained information and preparing a proposition for appropriate authority. The very activity may be undertaken by close observation or surveillance with the aim of gathering information which may be valuable for establishing whether there is grounds for suspicion that a crime or a misdemeanor has been committed (Law on Police, 2016, art. 50, para. 1) even before there are grounds for suspicion that a crime or a misdemeanor has been committed. This Law states that observation may be carried out in public and other accessible areas, excluding intrusion into any individual's right to privacy (art. 50, para. 2). When the assessment of the value of thus obtained information is concerned, the legislator has explicitly provided for a method for handling the information that may not be used in the procedure, as well as the information of no operational value, stipulating that they have to be destroyed within the period of one year (art. 50, para. 3). On the basis of this legal regulation, it may be concluded that police observation or surveillance may be treated as an activity undertaken ante delictum and post delictum, while the information obtained by this activity may have either operational or evidential value in proceeding a particular crime or misdemeanor. Apart from a general statement that observation must not intrude on a person's privacy, neither special guarantees are provided for, nor specific conditions for undertaking this activity are defined for the protection of the right to privacy.

There are no by-laws regulating a police officer's duties and activities that offer additional information on the specific application of thermal imaging cameras. The Regulation on Police Discharge of Particular Duties only contains a provision defining an activity titled close observation, monitoring and surveillance (art. 10). Similarly, Regulation on Police Powers does not contain special provisions either on conducting observation and 
surveillance, or regarding the application of thermal imaging cameras, except for general remarks on the possibility of performing particular operational tactical measures and actions by using special devices or technical means (art. 60, para. 5).

In order to completely analyze the application of police observation by thermal imaging cameras, we have studied the Law on Protection of State Border. According to this law, a border police officer may administer powers with the use of technical means and devices while performing border control duties (art. 28, para. 1). Additionally, this law stipulates that the surveillance of the state border is performed by administering powers and carrying out measures and actions directly or by using technical means and devices (art. 31). The regulation on Police Discharge of Particular Duties explicitly provides for the possibility of technical means application in protecting the state border, emphasizing that devices are used for that purpose without concretizing the type (art. 35, para 2).

More information on police observation may be found in criminalistics theory, where this activity is defined as general operational tactical or evidentiary action undertaken with regard to particular persons, objects and areas (Žarković, Ivanović, 2014, p. 163). Moreover, terms covert surveillance or special observation are in use, as well (Simonović, 2004, p. 120). Regardless of different names, basic features of observation are that it is performed covertly by selected and trained persons equipped with adequate technical means (Popara, 2012, p. 156). Police observation is the basis for undertaking other operational tactical measures and actions (Žarković, Ivanović, 2014, p. 163). In the course of surveillance, it is customary to use adequate technical means, such as infrared cameras, etc. (Žarković, Ivanović, 2014, p. 165).

It should be emphasized that thermal imaging cameras might be used in the course of covert surveillance of particular persons with the aim of observing their activities and contacts. Some authors point out that covert surveillance is a technique by which more than $50 \%$ of evidence in most police operational processing of organized criminal groups is obtained (Popara, 2010, p. 240). However, in the cases of covert surveillance, we must have in mind its twofold legal nature. Namely, covert surveillance may be understood either as a general operational tactical activity, or an activity undertaken within the special evidentiary action of covert surveillance and recording in accordance with article 171 of the Criminal Procedure Code. Covert surveillance implies secret observation of particular persons or a group of people and objects under operational processing, and it involves secret observation and surveillance with the aim of detecting particular criminalistics and criminal proceedings-relevant facts (Krivokapić, Žarković, Simonović, 2003, p.183).

As a rule, observation as a general operational tactical action is undertaken on the basis of the authorization given by the head of the 
department, supervising the unit for surveillance (Popara, 2010, p. 241). If secret observation is part of evidentiary action of covert surveillance and recording, then the conditions for their authorization are more rigorous, because this action is authorized by the preliminary proceedings judge. The time span of this special evidentiary action is legally limited and the control of its legality is carried out by preliminary proceedings judge.

Based on the above analysis, it may be concluded that adequate protection of the right to privacy is provided for by law if covert surveillance is undertaken as part of special evidentiary action of surveillance and recording. Thereby, potential application of thermal imaging cameras would be within the legal framework. The problem may arise if the police observation with the use of thermal imaging cameras is undertaken as operational tactical activity with the lack of precise provisions. Similar situation may be noticed in the legislation of the Republic of Slovenia, but the court practice there has taken the standpoint that the use of technical means has to be based on the court order (Kriznar, 2017, p. 200).

The Police Powers and Duties Act of the Republic of Croatia defines covert police actions as a special police power by which the identity of a person reasonably suspected of being the perpetrator of an offence prosecuted ex officio may be secretly checked (art. 32, para. 1). Covert verification of identity is undertaken by observation, surveillance, the gathering of information whilst the purpose of gathering and the status of a police officer are disguised by means of technical recording (art.32, para. 2). If not otherwise provided for by a separate law, it is specified that surveillance and technical recording measures may last for 24 hours at most, unless the measures have been undertaken in order to check the identity of a person suspected of committing offences for which the prescribed sentence is at least five years of imprisonment, in which case the measures may last for 48 hours (art. 32, para. 3).

The Police Powers and Duties Act of the Republic of Croatia provides for the possibility of undertaking covert police actions, such as observation and surveillance in the course of criminal investigation if it is evident that other actions shall not achieve the aims of police duties (art. 80, para. 1 and 2). Additionally, it is stipulated that observation and surveillance actions may last for fifteen days starting from the day of the order issuing, which may be extended by another fifteen days for reasons of successful completion of undertaken actions. The written order for observation and surveillance is issued by the general police director or some other person authorized by him, while in case of extension of the surveillance action, the order can be issued exclusively by the general director or his deputy. Exceptionally, the order may be placed orally if so required for reasons of urgency, but has to be issued in the written form within 24 hours (art. 80, para. 4 and 5). The law precisely defines that an authorized public prosecutor and the general police director have to be informed about the undertaken covert observation and 
surveillance actions with the aim of supervising their legality within 48 hours after the completion of the action (art. 80, para. 7). This law also provides for the civil control of the undertaken observation and surveillance actions (art. 102a).

Similarly, the Regulation on Police Discharge of Duties of the Republic of Croatia specifies that the observation and surveillance may be performed by means of adequate technical and program solutions (art. 120a) and it is the duty of the superior officer to check whether the used technical devices are in good working order after the completion of the action (art. 171).

On the basis of the above mentioned, we may conclude that there is sufficient room in the Serbian legislation for the improvement of laws and by-laws which would in detail regulate the legal basis (i.e. material and formal condition) for undertaking operational tactical police observation, the duration of the action, the control of its performance, the application of adequate technical devices, including thermal imaging cameras and defining their operational importance.

\section{CONCLUSION}

The use of thermal imaging cameras in crime detection as an additional technical device may help in obtaining information on excessive heat emission in a particular area. Thus obtained information is not sufficient for making conclusions implying that a criminal activity might be taking place on a certain location. Hence, these devices should exclusively be characterized as indications due to which other police measures and actions in crime detection may be realized. Furthermore, based on thermal imaging scanning and other undertaken police measures and actions (e.g. obtained information about electric power consumption), material basis for a search may be strengthened.

Since thermal imaging cameras enable recording of excessive heat emission, we are of the opinion that their application does not considerably violate the right to privacy. However, this right might be brought into question by undertaking some other operational tactical measures and actions, such as police observation, due to vague legal provisions. Hence, we are of the opinion that full protection of the right to privacy would be achieved by regulating police surveillance modelled after the Croatian legislative solution, as well as by stipulating the possibility for the application of thermal imaging cameras to facilitate crime detection. Thus, the citizens would be acquainted with the options at police officers' disposal to detect crimes, conditions and methods of their application, as well as legal means that they may use in order to control the legality of police actions involving the use of thermal imaging cameras, and the storing and processing of thus obtained information. 
The U.S. court practice supports the argument according to which a court order is required for the application of thermal imaging cameras because technology seems to be advancing at an unprecedented pace. Consequently, it is only a matter of time when thermal imaging cameras will be able to detect more than ordinary heat emission. We think that the employment of technology should be regulated taking into consideration its current performances, and not its overall potential, althewhile "keeping pace with everyday life" in order to ensure the full protection of human rights and freedoms.

\section{REFERENCES}

Alyushin, M., Kolobashkina, L., Person's face thermal image vibrational components processing in order to assess his current psycho-emotional state, Postproceedings of the 9th Annual International Conference on Biologically Inspired Cognitive Architectures, BICA 2018 (Ninth Annual Meeting of the BICA Society) Procedia Computer Science 145 (2018) 43-47.

Asirdizer, M., Hekimoglu, Y., Gumus, O. (2016) Usage of Infrared-Based Technologies in Forensic Sciences. Available at https://www.intechopen.com/books/forensicanalysis-from-death-to-justice/usage-of-infrared-based-technologies-in-forensicsciences, retrieved Oct $2^{\text {nd }} 2019$.

Battalwar P, Gokhale J, Bansod U. (2015). Infrared thermography and IR camera. International Journal of Research in Science \& Engineering, 1 (3), 9-14.

Campis, P.J. (2001). The Fourth Amendment and New Tchnologies: The Constitutionality of Thermal Imaging. Villanova Law Review, Vol. 46, 241, 246-275. Available at:http://digitalcommons.law.villanova.edu/vlr/vol46/iss1/7

Chua, J., Dyer, A., Garcia, J. Hot Shoes in the Room: Authentication of Thermal Imaging for Quantitative Forensic Analysis. Journal of. Imaging, 4, 1-11.

Crocker, P.T. (2013). Order, Technology, and the Constitutional Meanings of Criminal Procedure. The Journal of Criminal Law \& Criminology, Vol. 103, 3, 686-744. Available at: HeinOnline, 20.5.2019.

Dashiell, C. (2003). Thermal Imaging: Creating a Virtual Space. University of Toledo Law Review, 34, 351-372. Available at: HeinOnline, 20.5.2019.

De Broux S., McCaul K. K., Shimamoto, S. (2007). Infrared Photography. Available at https://www.crime-sceneinvestigator.net/Infrared_Photography_research_paper.pdf, retrieved Oct $2^{\text {nd }} 2019$.

Edelman GJ, Hoveling RJ, Roos M, van Leeuwen TG, Aalders MC. (2013). Infrared imaging of the crime scene: Possibilities and pitfalls. Journal of Forensic Sciences, 58(5), 1156-1162.

Krivokapić, V., Žarković, M., Simonović, B. (2003). Kriminalistika taktika [Criminalistics Tactics], Beograd: Viša škola unutrašnjih poslova.

Kriznar, P. (2017). The Question of Lawful Usage of Thermal Imaging Device in Criminal Procedure. Pravnik, 134, 3-4, 183-207. Available at: HeinOnline, 20. 5. 2019.

Kyllo v. United States, (99-8508) 533 U.S. 27 (2001). Available at: https://www.law. cornell.edu, 12.6.2019.

Larks-Stanford, A. (2000). The Warrantless Use of Thermal Imaging and "Intimate Details": Why Growing Pot Indoors and Washing Dishes are Similar Activities Under the Fourth Amendment. Catholic University Law Review, Vol. 49, 2, 575612. Available at:http://scholarship.law.edu/lawreview/vol49/iss2/8 
Lin AC, Hsieh HM, Tsai LC, Linacre A, Lee JC. (2007). Forensic applications of infrared imaging for the detection and recording of latent evidence. Journal of Forensic Sciences, 52 (5), 1148-1150.

McKenzie, D. (2002). What Were They Smoking: The Supreme Court's Latest Step in a Long, Strange Trip throught th Fourth Amendment, The Journal of Criminal Law \& Criminology, Vol. 93, 1, 153-194. Available at: HeinOnline, 20.5.2019.

Nikač, Ž., Radovanović, R., Zorić, V. (2018). Privatna bezbednost u Srbiji - pravni osnovi i edukacija pripadnika [Private Security in Serbia - Legal Basis and Education Members]. Teme, 1, 203-223. doi: 10.22190/TEME1801203N

Popara, V. (2010). Specifičnosti postupanja jedinica za opservaciju prilikom realizacije kontrolisane isporuke [Specific Features of Surveillance Unit Activities Upon Controlled Drug Deliveries]. Bezbednost, 1, 238-257.

Popara, V., Žarković, I. (2012). Kriminalistička opservacija u ruralnim uslovima [Criminalistic Surveillance in Conditions Rural Areas]. Bezbednost, 2, 151-171.

Pravilnik o načinu postupanja policijskih službenika, Narodne novine. Br. 89 (2010) i 76 (2015).

Pravilnik o načinu postupanja policijskih službenika, Službeni glasnik RS. Br. 63 (2018) i 72 (2018).

Pravilnik o policijskim ovlašćenjima, Službeni glasnik RS. Br. 41 (2019).

Simonović, B. (2004). Kriminalistika [Criminalistics], Kragujevac: Pravni fakultet u Kragujevcu i Institut za pravne i društvene nauke.

U.S. Department of Justice, Office of Justice Programms, National Institute of Justice (1996). Scoping Out Night Vision, 1-8. Available at: https://nij.ojp.gov. publications, 20.5.2019.

Zakon o graničnoj kontroli, Službeni glasnik RS. Br. 24 (2018).

Zakon o policiji, Službeni glasnik RS. Br. 6 (2016), 24 (2018) i 87 (2018).

Zakonik o krivičnom postupku, Službeni glasnik RS. Br. 72 (2011), 101 (2011), 121 (2012), 32 (2013), 45 (2013), 55 (2014) i 35 (2019).

Žarković, M., Ivanović, Z. (2014). Kriminalistička taktika [Criminalistics Tactics], Beograd: Kriminalističko-policijska akademija.

Zhang YC, Wang ZK, Fu XB, Yan F., Kong T. (2019). An experimental method for improving temperature measurement accuracy of infrared thermal imager. Infrared Physics \& Technology, 102, 103020.

\section{ПРИМЕНА ТЕРМОВИЗИЈСКИХ КАМЕРА У ДЕТЕКЦИЈИ КРИМИНАЛА}

Тања Кесић, Ивана Бјеловук

Криминалистичко-полицијски универзитет, Београд, Србија

\section{Резиме}

У заштити безбедности, односно у откривању и доказивању кривичних дела, полицијски службеници све више користе савремену технологију, међу којима се издваја и употреба термовизијских камера. Термовизијске камере функционишу тако што бележе емисију топлоте, претварајући инфрацрвену радијацију у радијацију која је видљива људском оку. На тај начин могу се открити различите криминалне активности, од незаконите производње марихуане, трговине људима, кријумчарења људи до надзора државне границе. 
У САД примена термовизијских уређаја изазвала је много контроверзи, пре свега са аспекта заштите права на приватност, предвиђеног Четвртим амандманом. У изостанку прецизног законског овлашћења на употребу термовизијских камера, америчка судска пракса покушала је да понуди одговоре на кључна питања, као што су законитост њихове употребе и дозвољеност употребе тако добијених информација у кривичном поступку. У почетку, већина судова сматрала је да се термовизијске камере могу користити без посебне судске наредбе за претресање, правдајући овакав став различитим аргументацијама. Прекретницу у судској пракси доноси пресуда Врховног суда САД у предмету Killo vs. United States, у којој је суд оценио да је за примену термовизијских уређаја неопходно обезбедити судску наредбу.

Имајући у виду недоумице које у пракси америчких судова изазвала примена термовизијских камера у откривању и доказивању кривичних дела, анализирали смо нормативна решења у Републици Србији. Анализом смо обухватили најважније прописе који регулишу поступање полицијских службеника. Свима њима заједничко је да не садрже посебне одредбе о употреби термовизијских камера, већ би се њихова употреба могла подвести под опште одредбе ових прописа, којима се предвиђа могућност коришћења техничких средства при вршењу полицијских овлашћења. Полазећи од анализе оперативно-тактичких мера и радњи код којих је употреба ових уређаја могућа, закључили смо да би се они могли користити при полицијском опажању, као и приликом предузимања посебне доказне радње, тајно праћење и снимање. У зависности од тога да ли се користе при предузимању полицијског опажања или тајног праћења и снимања, услови за примену термовизијских камера били би идентични као за предузимање радње при чијем спровођењу се користе. Будући да оперативно-тактичка радња полицијско опажање није прецизно уређена прописима, самим тим и питање примене термовизијских камера остаје без одговора. Мишљења смо да би законом требало предвидети могућност коришћења термовизијских камера при спровођењу полицијског опажања, а информације добијене њиховом применом третирати као информације од оперативног значаја. Посебна вредност информација добијених применом термовизијских камера огледа се у оснаживању правног основа за предузимање појединих доказних радњи, као што су претресање и тајно праћење и снимање. 